\title{
Conductance of Electrolytes in 1-Propanol Solutions from -40 to $25{ }^{\circ} \mathrm{C}$
}

\author{
J. Barthel, ${ }^{1}$ R. Wachter, ${ }^{1}$ G. Schmeer, ${ }^{1}$ and \\ H. Hilbinger ${ }^{1}$ \\ Received October 16, 1985; revised February 6, 1986
}

Conductance data for solutions of $\mathrm{LiCl}, \mathrm{NaBr}, \mathrm{NaI}, \mathrm{KI}, \mathrm{KSCN}, \mathrm{RbI}, \mathrm{Et}_{4} \mathrm{NI}$, $\mathrm{Pr}_{4} \mathrm{NI}, \quad \mathrm{Bu} u_{4} \mathrm{NI}, \quad \mathrm{Bu}_{4} \mathrm{NClO}_{4}, \quad n-\mathrm{Am}_{4} \mathrm{NI}, \quad \mathrm{i}-\mathrm{Am}_{4} \mathrm{NI}, \quad n-\mathrm{Hept}_{4} \mathrm{NI}, \quad \mathrm{Me}_{2} \mathrm{Bu}_{2} \mathrm{NI}$, $\mathrm{MeBu}_{3} \mathrm{NI}, \mathrm{EtB} u_{3} \mathrm{NI}, \mathrm{i}-\mathrm{Am} \mathrm{m}_{3} \mathrm{BuNI}$, and $i-\mathrm{Am}_{3} \mathrm{BuNBPh}_{4}$ in 1-propanol at -40 , $-30,-20,-10,0,10$, and $25^{\circ} \mathrm{C}$ are communicated and discussed. Evaluation of the data is performed on the basis of a conductance equation that includes a term in $c^{3 / 2}$. Single ion conductances at 25 and $10^{\circ} \mathrm{C}$ are determined with the help of transference numbers $t_{0}^{+}(\mathrm{KSCN} / \mathrm{PrOH})$; the data are compared to data estimated by other methods. Ion-pair association constants and their temperature dependence are discussed in terms of contact and solvent separated ion pairs, and the role of non-coulombic forces is shown with the help of an appropriate splitting of the Gibbs energy of ion-pair formation.

KEY WORDS: Electrolyte conductance; single ion conductance; ion-pair formation; non-coulombic interactions; 1-propanol solutions; alkali metal salts; tetraalkylammonium salts.

\section{INTRODUCTION}

The temperature dependences of conductance and transference numbers of electrolytes in nonaqueous solutions are the subject of a comprehensive study in our laboratory aimed at an understanding of ion-ion and ion-solvent interactions in these solutions. This paper continues the study on alcohol solutions that began with ethanol solutions. ${ }^{(1)}$ Transference numbers are given in Ref. 2.

For the standard methods of measurement and data analysis, which is based on the chemical model (CM) of electrolyte solutions including short range interactions, ${ }^{(3,4)}$ the reader is referred to Refs. 1

Institut für Physikalische und Theoretische Chemie, Universität Regensburg, Federal Rep. of Germany. 
and 2. Conductance data were analyzed with the help of the seriesdeveloped Fuoss-Hsia equation (coefficients in Ref. 5), which was adapted to the CM by appropriate distance parameters $R$.

$$
\begin{gathered}
\Lambda=\alpha\left[\Lambda_{0}-S(\alpha c)^{1 / 2}+E^{\prime} \alpha c \ln \alpha c+J_{1}(R) \alpha c+J_{2}(R)(\alpha c)^{3 / 2}\right] \\
\frac{1-\alpha}{\alpha^{2} c}=K_{y_{ \pm}}^{\prime 2} ; \quad y_{ \pm}^{\prime}=\exp \left[-\frac{\kappa q}{1+\kappa R}\right] \quad(1 \mathrm{~b} \mathrm{a}
\end{gathered}
$$

In Eqs. (1), $\Lambda$ is the molar conductance at molar concentration $c$, and $\Lambda_{0}$ is its limiting value; $(1-\alpha)$ is the fraction of oppositely charged ions acting as ion pairs; $K_{\mathrm{A}}$ is the thermodynamic association constant, and $y_{ \pm}^{\prime}$ is the activity coefficient of the dissociated fraction of the electrolyte; $R$ is the distance up to which oppositely charged ions are considered to be ion pairs. The quantities $q$ and $\kappa$ are given by (cgs units)

$$
q=e^{2} / 2 \epsilon k T ; \quad \kappa^{2}=16 \times 10^{-3} \pi q N_{\mathrm{A}} \alpha c
$$

The symbols of Eqs. (2) have their usual meaning; $e$ is the elementary charge, $\epsilon$ is the relative permittivity of the solvent, $N_{\mathrm{A}}$ is Avogadro's number, $k$ is the Boltzmann constant, and $T$ is the Kelvin temperature.

Data analysis commonly is based on the use of independent distance parameters $R=R\left(y_{ \pm}^{\prime}\right), R_{1}=R\left(J_{1}\right)$, and $R_{2}=R\left(J_{2}\right)$ to yield four, three, and two parameter fits. ${ }^{(1,5)}$ In this paper, we used three parameter fits for which $R_{1}$ was fixed to $R$; the final values of $\Lambda_{0}, K_{\mathrm{A}}$, and $R_{2}$ were obtained by nonlinear least squares iteration. ${ }^{(1)}$ Only the solutions of $i-\mathrm{Am}_{3} \mathrm{BuNBPh}_{4}$ required a two parameter fit, $R_{2}=R_{1}=$ $R$, as a consequence of limited solubility ranges.

As usual in CM calculations, the upper distance $R$ of ion-pair formation for alkali metal and tetraalkylammonium salts in alcohol solutions was fixed to the sum of closest ion approach, $a$ or $a^{\prime}$, and the dimension of an orientated solvent molecule (1-propanol, $s=6.9 \mathrm{~A}$ ). ${ }^{(1)}$ The distance of closest approach $a$ for the tetraalkylammonium, cesium, rubidium, and potassium salts is the contact distance of cation and anion, $a=a_{+}+a_{-}$. The data from lithium and sodium salt solutions were analyzed by fixing the distance of closest approach to $a^{\prime}=$ $a+d_{\mathrm{OH}}$, i.e., when assuming that the mutual distance of cation and anion includes at least one OH-length $\left(d_{\mathrm{OH}}=2.8 \mathrm{~A}\right)$, and a solvent separated ion pair is formed. When analyzed with the help of $a=a_{+}$ $+a_{-}$, the data from lithium and sodium salts exhibit the same inconsistencies within the pattern of enthalpies and entropies of association 
Table I. Experimental Results from Solvent Property Determinations and Conductance Measurements on Various Salts

\begin{tabular}{|c|c|c|c|c|c|c|c|}
\hline & $25^{\circ} \mathrm{C}$ & $10^{\circ} \mathrm{C}$ & $\mathrm{o}^{\circ} \mathrm{C}$ & $-10^{\circ} \mathrm{C}$ & $-20^{\circ} \mathrm{C}$ & $-30^{\circ} \mathrm{C}$ & $-40^{\circ} \mathrm{C}$ \\
\hline \multicolumn{8}{|c|}{ Solvent Properties } \\
\hline$d$ & 0.79954 & 0.81150 & 0.81941 & 0.82728 & 0.83513 & 0.84299 & 0.85090 \\
\hline$\varepsilon$ & 20.436 & 22.567 & 24.093 & 25.711 & 27.430 & 29.258 & 31.205 \\
\hline$\pi$ & 1.967 & 2.840 & 3.710 & 4.947 & 6.748 & 9.442 & 13.600 \\
\hline$\tilde{m} \times 10^{4}$ & \multicolumn{7}{|c|}{ Molar Conductances, $A$} \\
\hline \multicolumn{8}{|c|}{ LiC1: $a=2.59 ; D=0.036 ; M_{E}=42.39$} \\
\hline 3.1481 & 17.804 & 12.299 & 9.3909 & 7.0333 & 5.1547 & 3.6866 & 2.5617 \\
\hline 8.7980 & 16.152 & 11.347 & 8.7358 & 6.5845 & 4.8502 & 3.4834 & 2.4279 \\
\hline 16.9269 & 14.732 & 10.502 & 8.1467 & 6.1783 & 4.5740 & 3.2978 & 2.3058 \\
\hline 23.3535 & 13.948 & 10.023 & 7.8083 & 5.9427 & 4.4127 & 3.1894 & 2.2343 \\
\hline 30.4632 & 13.267 & 9.5992 & 7.5072 & 5.7314 & 4.2671 & 3.0909 & 2.1690 \\
\hline 37.3280 & 12.740 & 9.2647 & 7.2682 & 5.5631 & 4.1496 & 3.0107 & 2.1162 \\
\hline 44.8130 & 12.248 & 8.9504 & 7.0396 & 5.4011 & 4.0371 & 2.9341 & 2.0647 \\
\hline $53.669 \uparrow$ & 11.765 & B. 6375 & 6.8109 & 5.2372 & 3.9224 & 2.8555 & 2.0124 \\
\hline \multicolumn{8}{|c|}{ NaBr: $a=2.94 ; D=0.084 ; M_{E}=102.89$} \\
\hline 2.5839 & 20.475 & 14.188 & 10.863 & 8.1582 & 5.9985 & 4.3040 & 2.9967 \\
\hline 8.2454 & 18.478 & 13.030 & 10.062 & 7.6075 & 5.6223 & 4.0514 & 2.8294 \\
\hline 11.6916 & 17.697 & 12.565 & 9.7379 & 7.3831 & 5.4682 & 3.9467 & 2.7605 \\
\hline 15.6290 & 16.970 & 12.128 & 9.4307 & 7.1689 & 5.3219 & 3.8475 & 2.6952 \\
\hline 19.4843 & 16.385 & 11.770 & 9.1770 & 6.9912 & 5.1987 & 3.7651 & 2.6370 \\
\hline 25.7675 & 15.607 & 11.289 & $8.832 B$ & 6.7504 & 5.0332 & 3.6515 & 2.5646 \\
\hline 35.2604 & 14.703 & 10.717 & 8.4217 & 6.4593 & 4.8297 & 3.5128 & 2.4722 \\
\hline 46.7632 & 13.871 & 10.179 & 8.0319 & 6.7807 & 4.6345 & 3.3786 & 2.3820 \\
\hline 59.5087 & 13.161 & 9.7152 & 7.6908 & 5.9343 & 4.4605 & 3.2586 & 2.3014 \\
\hline \multicolumn{8}{|c|}{ NaI: $a=3.18 ; D=0.112 ; M_{E}=149.89$} \\
\hline 1.8578 & $22: 677$ & 15.674 & 12.008 & 9.0328 & 6.6543 & 4.7910 & 3.3470 \\
\hline 3.9685 & 21.795 & 15.150 & 11.636 & 8.7716 & 6.4750 & 4.6659 & 3.2637 \\
\hline 7.5119 & 20.784 & 14.563 & 11.208 & 8.4704 & 6.2655 & 4.5232 & 3.1684 \\
\hline 10.7557 & 20.079 & 14.116 & 10.905 & 8.2590 & 6.1179 & 4.4227 & 3.1004 \\
\hline 15.0183 & 19.348 & 13.672 & 10.588 & 8.0328 & 5.9619 & 4.3145 & 3.0286 \\
\hline 21.0104 & 18.537 & 13.170 & 10.229 & 7.7798 & 5.7856 & 4.1937 & 2.9474 \\
\hline 29.3884 & 17.675 & 12.629 & 9.8409 & 7.5032 & 5.5916 & 4.0601 & 2.8577 \\
\hline \multirow[t]{2}{*}{39.5618} & 16.862 & 12.119 & 9.4694 & 7.2379 & 5.4043 & 3.9314 & 2.7703 \\
\hline & $K I: a=$ & 3; $D=0$ & $M_{E}=16$ & & & & \\
\hline 2.1970 & 23.753 & 16.516 & 12.681 & 9.5493 & 7.0386 & 5.0639 & 3.5349 \\
\hline 6.0539 & 21.883 & 15.426 & 91.926 & 9.0320 & 6.5898 & 4.8318 & 3.3838 \\
\hline B. 4060 & 21.056 & 14.932 & 11.581 & 8.7935 & 6.5275 & 4.7231 & 3.3131 \\
\hline 11.4719 & 20.226 & 14.429 & 11.227 & 8.5484 & 6.3595 & 4.6112 & 3.2412 \\
\hline 15.7321 & 19.280 & 13.848 & 10.816 & 8.2611 & 6.1627 & 4.4792 & 3.1536 \\
\hline 20.3205 & 18.480 & 13.346 & 10.455 & 8.0078 & 5.9887 & 4.3611 & 3.0763 \\
\hline
\end{tabular}


Table I. Continued

\begin{tabular}{|c|c|c|c|c|c|c|c|}
\hline$\tilde{m} \times 10^{4}$ & $25^{\circ} \mathrm{C}$ & $10^{\circ} \mathrm{C}$ & $0^{\circ} \mathrm{C}$ & $-10^{\circ} \mathrm{C}$ & $-20^{\circ} \mathrm{C}$ & $-30^{n} c$ & $-40^{n} \mathrm{c}$ \\
\hline & \multicolumn{7}{|c|}{$\operatorname{KSCN}: a=4.73 ; D=0.054 ; M_{\mathbf{E}}=97.18$} \\
\hline 4.4455 & 23.078 & 16.185 & 12.483 & 9.4353 & 6.9740 & 5.0278 & 3.5155 \\
\hline 10.1738 & 21.094 & 14.995 & 11.650 & 8.8589 & 6.5829 & 4.7660 & 3.3445 \\
\hline 13.8290 & 20.211 & 14.455 & 11.266 & 8.5923 & 5.3989 & 4.6433 & 3.2647 \\
\hline 18.9785 & 19.230 & 13.844 & 10.829 & 8.2858 & 6.1894 & 4.5021 & 3.1723 \\
\hline 26.7622 & 18.108 & 13.133 & 10.317 & 7.9225 & 5.9383 & 4.3320 & 3.0601 \\
\hline 36.8051 & 17.031 & 12.437 & 9.8094 & 7.5609 & 5.6854 & 4.1598 & 2.9463 \\
\hline \multirow[t]{2}{*}{52.4104} & 15.824 & 11.641 & 9.2226 & 7.1386 & 5.3883 & 3.9557 & 2.8098 \\
\hline & \multicolumn{7}{|c|}{$\mathrm{RbI}: \mathrm{a}=3.69 ; \mathrm{D}=0.14 ; \mathrm{M}_{\mathrm{E}}=212.37$} \\
\hline 1.0168 & 24.945 & 17.312 & 13.286 & 10.004 & 7.3785 & 5.3122 & 3.7099 \\
\hline 2.2007 & 23.959 & 16.749 & 12.901 & 9.7440 & 7.2024 & 5.1946 & 3.6358 \\
\hline 4.8016 & 22.354 & 15.797 & 12.237 & 9.2865 & 6.8944 & 4.9904 & 3.5025 \\
\hline 6.4090 & $2 \dagger .614$ & 15.351 & 11.923 & 9.0594 & 6.7455 & 4.8916 & 3.4383 \\
\hline 10.8867 & 20.051 & 14.391 & 11.243 & 8.5945 & 6.4198 & 4.6721 & 3.2953 \\
\hline \multirow[t]{2}{*}{20.7499} & 17.869 & 13.003 & 10.237 & 7.8805 & 5.9229 & 4.3348 & 3.0718 \\
\hline & \multicolumn{7}{|c|}{$E t_{4}{ }^{N I:} a=6.20 ; D=0.09 ; M_{E}=257.16$} \\
\hline 0.8228 & 27.343 & 18.931 & 14.517 & 10.925 & 8.0491 & 5.7804 & 4.0376 \\
\hline 1.5645 & 26.487 & 18.378 & 14.101 & 10.615 & 7.8232 & 5.6249 & 3.9217 \\
\hline 1.7803 & 26.271 & 18.232 & 13.990 & 10.532 & 7.7595 & 5.5775 & 3.8871 \\
\hline 2.7900 & 25.390 & 17.647 & 13.552 & 10.205 & 7.5184 & 5.4016 & 3.7606 \\
\hline 3.2998 & 24.986 & 17.381 & 13.350 & 10.053 & 7.4052 & 5.3179 & 3.7013 \\
\hline 4.5188 & 24.162 & 16.832 & 12.833 & 9.7400 & 7.1723 & 5.1487 & 3.5787 \\
\hline 4.5974 & 24.120 & 16.804 & 12.913 & 9.7239 & 7.1619 & 5.1414 & 3.5738 \\
\hline 6.2022 & 23.266 & 16.202 & 12.455 & 9.3793 & 6.9052 & 4.9524 & 3.1486 \\
\hline 7.4359 & 22.642 & 15.807 & 12.154 & 9.1528 & 6.7367 & 4.8301 & - \\
\hline 8.8666 & 22.042 & 15.396 & 11.846 & 8.9193 & 6.5631 & 4.7036 & - \\
\hline 10.8742 & 21.305 & 14.903 & 11.464 & 8.6331 & 6.3511 & 4.5480 & - \\
\hline \multirow[t]{2}{*}{16.3348} & 99.766 & 13.845 & 10.654 & - & - & - & - \\
\hline & \multicolumn{7}{|c|}{$\mathrm{Pr}_{4} \mathrm{NI}: a=6.72 ; D=0.09 ; \mathrm{M}_{\mathrm{E}}=313.26$} \\
\hline 0.9616 & 24.647 & 17.002 & 13.000 & 9.7515 & 7.1617 & 5.1308 & 3.5655 \\
\hline 3.0560 & 22.873 & 15.831 & 12.116 & 9.0900 & 6.6726 & 4.7744 & 3.3095 \\
\hline 6.2588 & 21.124 & 14.663 & 11.226 & 8.4222 & 6.1759 & 4.4112 & 3.0494 \\
\hline 9.6401 & 19.910 & 13.834 & 10.596 & 7.9457 & 5.8204 & 4.1511 & 2.8639 \\
\hline 13.5497 & 18.734 & 13.031 & 9.9818 & 7.4807 & 5.4745 & 3.8983 & 2.6846 \\
\hline 21.1079 & 17.177 & 11.961 & 9.1587 & 6.8570 & 5.0108 & 3.5603 & 2.4441 \\
\hline 29.1517 & 16.003 & 11.147 & 8.5381 & 6.3852 & 4.6603 & 3.3044 & 2.2628 \\
\hline \multirow[t]{2}{*}{45.3120} & 14.387 & 10.024 & 7.6682 & 5.7292 & 4.1726 & 2.9504 & 2.0134 \\
\hline & \multicolumn{7}{|c|}{$\mathrm{BU}_{4} \mathrm{NI}: \mathrm{a}=7.14 ; \mathrm{D}=0.098 ; M_{\mathrm{E}}=369.37$} \\
\hline 0.6341 & 23.483 & 16.191 & 12.377 & 9.2851 & 6.8204 & 4.8902 & 3.4011 \\
\hline 2.1689 & 22.023 & 15.221 & 11.644 & 8.7415 & 6.4172 & 4.5975 & 3.1926 \\
\hline 3.6748 & 20.899 & 14.470 & 11.075 & 8.3134 & 6.1001 & 4.3640 & 3.0264 \\
\hline 5.8355 & 19.983 & 13.852 & 10.607 & 7.9580 & 5.8370 & 4.1724 & 2.8876 \\
\hline B. 8584 & 18.793 & 13.046 & 9.9902 & 7.4932 & 5.4908 & 3.9190 & 2.7070 \\
\hline 11.4259 & 18.011 & 12.510 & 9.5794 & 7.1828 & 5.2587 & 3.7492 & 2.5858 \\
\hline 14.2793 & 17.290 & 12.015 & 9.1989 & 6.8945 & 5.0452 & 3.5925 & 2.4756 \\
\hline 20.7188 & 16.036 & & 8.5358 & 6.3882 & 4.6696 & 3.3184 & 2.2792 \\
\hline
\end{tabular}


Table I. Continued

\begin{tabular}{|c|c|c|c|c|c|c|c|}
\hline$\pi \times 10^{4}$ & $25^{\circ} \mathrm{C}$ & $10^{\circ} \mathrm{C}$ & $\mathrm{o}^{\mathrm{C}} \mathrm{C}$ & $-10^{\circ} \mathrm{C}$ & $-20^{\circ} \mathrm{C}$ & $-30^{\circ} \mathrm{C}$ & $-40^{\circ} \mathrm{C}$ \\
\hline & \multicolumn{7}{|c|}{$\mathrm{Bu}_{4} \mathrm{NClO}_{4}: a=7.34 ; D=0.070 ; \mathrm{M}_{\mathrm{E}}=341.92$} \\
\hline 1.0451 & 24.812 & 17.238 & 13.243 & 9.9820 & 7.3631 & 5.2968 & 3.6920 \\
\hline 3.2859 & 22.243 & 15.452 & 11.846 & 8.9003 & 6.5334 & 4.6671 & 3.2263 \\
\hline 6.6078 & 19.963 & 13.852 & 10.597 & 7.9352 & 5.7988 & 4.1184 & 2.8264 \\
\hline 13.4805 & 17.221 & 11.923 & 9.0942 & 6.7796 & 4.9261 & 3.4740 & 2.3639 \\
\hline 19.2582 & 15.778 & 10.906 & 8.3023 & 6.1740 & 4.4716 & 3.1415 & 2.2173 \\
\hline 26.3861 & 14.503 & 10.006 & 7.6036 & 5.6400 & 4.0721 & 2.8503 & 1.9221 \\
\hline 36.0952 & 13.256 & 9.1281 & 6.9209 & 5.1201 & 3.6843 & 2.5692 & 1.7245 \\
\hline \multirow[t]{2}{*}{48.1253} & 12.149 & 8.3461 & 6.3149 & 4.6588 & 3.3424 & 2.3212 & 1.5511 \\
\hline & \multicolumn{7}{|c|}{$n-A_{4} N I: a=7.45 ; D=0.108 ; M_{E}=425.48$} \\
\hline 1.0627 & .21 .895 & 15.113 & 11.566 & 8.6873 & 6.3884 & 4.5842 & 3.1905 \\
\hline 2.6433 & 20.635 & 14.271 & 10.924 & 8.2029 & 6.0275 & 4.3203 & 3.0017 \\
\hline 4.2525 & 19.682 & 13.629 & 10.438 & 7.8364 & 5.7549 & 4.1204 & 2.8582 \\
\hline 7.4003 & 18.326 & 12.711 & 9.7348 & 7.3045 & 5.3584 & 4.8304 & 2.6487 \\
\hline 11.6967 & 17.012 & 11.813 & 9.0470 & 6.7835 & 4.9694 & 3.5448 & 2.4459 \\
\hline 15.7414 & 16.088 & 11.177 & 8.5589 & 6.4137 & 4.6938 & 3.3431 & 2.3026 \\
\hline 22.3888 & 14.942 & 10.386 & 7.9490 & 5.9513 & 4.3490 & 3.0923 & 2.1237 \\
\hline 28.1478 & 14.180 & 9.8489 & 7.5423 & 5.6427 & 4.1191 & 2.9238 & 2.0050 \\
\hline \multirow[t]{2}{*}{42.6708} & 12.793 & 8.8901 & 6.7959 & 5.0763 & 3.6974 & $2.6+73$ & 1.7886 \\
\hline & \multicolumn{7}{|c|}{$1-\mathrm{Am}_{4} \mathrm{NI}: a=7.20 ; D=0.108 ; \mathrm{M}_{\mathrm{E}}=425.48$} \\
\hline 1.0611 & 22.082 & 15.224 & 11.640 & 8.7324 & 6.4153 & 4.5978 & 3.1965 \\
\hline 2.3214 & 20.994 & 14.502 & 11.092 & 8.3200 & 6.1079 & 4.3721 & 3.0340 \\
\hline 4.0337 & 19.896 & 13.760 & 10.527 & 7.8939 & 5.7903 & 4.1397 & 2.8668 \\
\hline 8.1722 & 18.089 & 12.533 & 9.5874 & 7.1837 & 5.2607 & 3,7513 & 2.5894 \\
\hline 11.6160 & 17.006 & 11.789 & 9.0174 & 6.7519 & 4.9385 & 3.5161 & 2.4214 \\
\hline 16.3008 & 15.913 & 11.036 & 8.4371 & 6.3124 & 4.6105 & 3.2765 & 2.2516 \\
\hline 24.3953 & 14.551 & 10.094 & 7.7114 & 5.7616 & 4.2001 & 2.9781 & 2.0404 \\
\hline 31.6968 & 13.655 & 9.4711 & 7.2316 & 5.3987 & 3.9301 & 2.7817 & 1.9023 \\
\hline \multirow[t]{2}{*}{40.2314} & 12.847 & 8.9046 & 6.7950 & 5.0666 & 3.6841 & 2.6031 & 1.7764 \\
\hline & \multicolumn{7}{|c|}{ n-Hept ${ }_{4} \mathrm{NI}: a=8.08 ; \quad D=0.119 ; M_{E}=537.69$} \\
\hline 0.4359 & 21.132 & 14.567 & 11.135 & 8.3603 & 6.1420 & 4.4012 & 3.0505 \\
\hline 1.2965 & 20.279 & 14.013 & 10.730 & 8.0617 & 5.9326 & 4.2585 & 2.9625 \\
\hline .2 .7010 & 19.297 & 13.361 & 10.237 & 7.6944 & 5.65 .95 & 4.0605 & 2.8233 \\
\hline 4.2704 & 18.438 & 12.785 & 9.7997 & 7.3648 & 5.4168 & 3.8834 & 2.6964 \\
\hline 6.2239 & 17.594 & 12.213 & 9.3633 & 7.0366 & 5.1721 & 3.7057 & 2.5691 \\
\hline 9.4560 & 16.520 & 11.481 & 6.8032 & 6.6124 & 4.8550 & 3.4724 & 2.4038 \\
\hline 15.8444 & 15.029 & 10.457 & 8.0167 & 6.0153 & 4.4091 & 3.1462 & 2.1726 \\
\hline \multirow[t]{2}{*}{21.2223} & 14.129 & 9.8341 & 7.5364 & 5.6526 & 4.1388 & 2.9489 & 2.0315 \\
\hline & \multicolumn{7}{|c|}{$\mathrm{MeBu}_{3} \mathrm{NI}: \mathbf{a}=5.67 ; \mathrm{D}=0.107 ; \mathrm{M}_{\mathrm{E}}=327.29$} \\
\hline 1.6749 & 22.956 & 15.872 & 12.144 & 9.1204 & 6.7003 & 4.8025 & 3.3372 \\
\hline 3.5208 & 21.502 & 14.905 & 11.416 & 8.5698 & 6.2945 & 4.5050 & 3.1224 \\
\hline 6.5575 & 19.845 & 13.793 & 10.571 & 7.9365 & 5.8231 & 4.1600 & 2.8753 \\
\hline 10.7098 & 18.299 & 12.744 & 9.7701 & 7.3313 & 5.3724 & 3.8311 & 2.6417 \\
\hline 15.2903 & 17.081 & 11.906 & 9.1286 & 6.8466 & 5.0119 & 3.5682 & 2.4551 \\
\hline 20.4845 & $16 .: 234$ & 11.187 & 0. 5775 & 6.4293 & 4.7011 & 3.3426 & 2.2945 \\
\hline 26.2046 & 15.145 & 10.569 & 8. 1023 & 6.0690 & 4.4 .336 & 3.1475 & 2.1570 \\
\hline 32.7629 & 14.333 & 10.008 & 7.6687 & 5.7408 & 4.1898 & 2.9703 & 2.0320 \\
\hline
\end{tabular}


Table I. Continued

\begin{tabular}{|c|c|c|c|c|c|c|c|}
\hline$\tilde{m} \times 10^{4}$ & $25^{\circ} \mathrm{C}$ & $10^{\circ} \mathrm{C}$ & $\mathrm{O}^{\circ} \mathrm{C}$ & $-10^{\circ} \mathrm{C}$ & $-20^{\circ} \mathrm{C}$ & $-30^{\circ} \mathrm{C}$ & $-40^{\circ} \mathrm{C}$ \\
\hline \multicolumn{8}{|c|}{$\mathrm{Me}_{2} \mathrm{Bu}{ }_{2} \mathrm{NI}: a=5.67 ; \mathrm{D}=0.102 ; \mathrm{M}_{E}=285.21$} \\
\hline 0.9751 & 24.663 & 17.037 & 13.043 & 9.7927 & 7.2003 & 5.1617 & 3.5885 \\
\hline 1.8572 & 23.667 & 16.392 & 12.557 & 9.4326 & 6.9349 & 4.9714 & 3.4528 \\
\hline 3.4684 & 22.308 & 15.491 & 11.878 & 8.9252 & 6.5591 & 4.6968 & 3.2568 \\
\hline 7.2456 & 20.166 & 14.057 & 10.785 & 8.1043 & 5.9528 & 4.2522 & 2.9407 \\
\hline 11.5838 & 18.545 & 12.955 & 9.9477 & 7.4727 & 5.4808 & 3.9106 & 2.6968 \\
\hline 18.4793 & 16.816 & 11.768 & 9.0393 & 6.7869 & 4.9705 & 3.5390 & 2.4330 \\
\hline 27.8712 & 15.252 & 10.687 & 8.2079 & 6.1583 & 4.5040 & 3.1994 & 2.1931 \\
\hline 42.8443 & 13.639 & 9.5634 & 7.3417 & 5.5012 & 4.0162 & 2.8454 & 1.9440 \\
\hline 59.5677 & 12.445 & 8. 7255 & 6.6936 & 5.0107 & 3.6514 & 2.5811 & 1.7582 \\
\hline \multicolumn{8}{|c|}{$\mathrm{EtBu}_{3} \mathrm{NI}: \mathrm{a}=6.20 ; \mathrm{D}=0.108 ; \mathrm{M}_{\mathrm{E}}=341.32$} \\
\hline 0.9995 & 23.860 & 16.460 & 12.584 & 9.4349 & 6.9247 & 4.9577 & 3.4345 \\
\hline 2.7875 & 22.296 & 15.437 & 11.818 & 8.8684 & 6.5100 & 4.6574 & 3.2272 \\
\hline 6.7490 & 20.164 & 13.998 & 10.727 & 8.0437 & 5.9046 & 4.2166 & 2.9140 \\
\hline 10.1079 & 18.947 & 13.177 & 10,097 & 7.5752 & 5.5526 & 3.9600 & 2.7309 \\
\hline 14.3815 & 17.790 & 12.383 & 9.4904 & 7.1156 & 5.2104 & 3.7118 & 2.5563 \\
\hline 20.4521 & 16.568 & 11.542 & 8.8424 & 6.6241 & 4.8459 & 3.4475 & 2.3682 \\
\hline 25.9872 & 15.717 & 10.954 & 8. 3903 & 6.2821 & 4.5924 & 3.2614 & 2.2358 \\
\hline 36.7183 & 14.483 & 10.092 & 7.7264 & 5.7792 & 4.2179 & 2.9891 & 2.0448 \\
\hline 46.3447 & 13.651 & 9.5135 & 7.2807 & 5.4407 & 3.9657 & 2.8073 & 1.9164 \\
\hline & \multicolumn{7}{|c|}{$1-\mathrm{Am}_{3} \mathrm{BUNI}: \mathrm{a}=7.18 ; \mathrm{D}=0.113 ; \mathrm{M}_{E}=411.46$} \\
\hline 1.3570 & 22.110 & 15.248 & 11.658 & 8.7437 & 6.4206 & 4.5997 & 3.1935 \\
\hline 2.8657 & 20.903 & 14,449 & 11.049 & 8.2871 & 6.0813 & 4.3520 & 3.0169 \\
\hline 5.9712 & 19.227 & 13.313 & 10.185 & 7.6353 & 5.5966 & 3.9965 & 2.7628 \\
\hline 11.1664 & 17.423 & 12.081 & 9.2424 & 6.9221 & 5.0645 & 3.6081 & 2.4858 \\
\hline 19.6208 & 15.580 & 10.814 & 8.2688 & 6.1849 & 4.5158 & 3.2072 & 2.2016 \\
\hline 29.8653 & 14.149 & 9.8179 & 7.5005 & 5.6029 & 4.0828 & 2.8924 & 1.9790 \\
\hline 40.4734 & 13.105 & 9.0919 & 6.9412 & 5.1781 & 3.7669 & 2.6631 & 1.8180 \\
\hline \multirow[t]{2}{*}{50.8879} & 12.333 & 8.5507 & 6.5232 & 4.8620 & 3.5322 & 2.4930 & 1.6983 \\
\hline & \multicolumn{7}{|c|}{$i-\mathrm{Am}_{3} \mathrm{BuNBPh}_{4}: a=9.74 ; \mathrm{D}=0.16 ; \mathrm{M}_{E}=603.79$} \\
\hline 0.10852 & 20.670 & 14.248 & 10.885 & 8.1451 & 5.9475 & 4.2301 & 2.9061 \\
\hline 0.38967 & 20.159 & 13.879 & 10.581 & 7.9050 & 5.7612 & 4.0866 & 2.7943 \\
\hline 0.53759 & 20.090 & 13.813 & 10.526 & 7.8424 & 5.7179 & 4.0494 & 2.7641 \\
\hline 0.71074 & 19.901 & $13.66 \mathrm{~B}$ & 10.408 & 7.7558 & 5.6389 & 3.3880 & 2.7153 \\
\hline 0.91637 & 19.625 & 13.471 & 10.247 & 7.6278 & 5.5384 & 3.9099 & 2.6576 \\
\hline 1.0871 & 19.461 & 13.353 & 10.145 & 7.5450 & 5.4723 & 3.8584 & 2.6174 \\
\hline 1.3040 & 19.233 & 13.177 & 10.007 & 7.4307 & 5.3840 & 3.7907 & 2.5677 \\
\hline 1.5265 & 19.020 & 13.016 & 9.8759 & 7.3283 & 5.3021 & 3.7282 & - \\
\hline
\end{tabular}

anits: density a, $g^{-c^{-3}}$; permittivity $E$, no; viscosity $n$, ep; molonity $\tilde{m}$, mol-(kg of solution) $)^{-1}$; molar conductance $A, S-\mathrm{cm}^{2}-m o l^{-1}$; distance parameter $a, \&$; density gradient $D, g^{-c m^{-3}-1 m o l-k y^{-1},-1}$; molar mass $\mathrm{M}_{E}, \mathrm{~g}-\mathrm{mol}^{-1}$; blanks, golubility limit is gurpassed. 
which were observed for these salts in ethanol solutions. The values for the $a$-parameters ${ }^{(4)}$ are quoted in Table I.

\section{EXPERIMENTAL}

\subsection{Materials}

1-Propanol (p.A. Merck) was dried with amalgamated aluminum shot; ${ }^{(6)}$ ammonia and amines were removed by boiling for twelve hours in the presence of sulfanilic acid. Subsequent distillation over a packed column (about 50 plates) ${ }^{(7)}$ reduced the water content to less than $10 \mathrm{ppm}$ and the specific conductance to less than $10^{-9} \mathrm{~S}-\mathrm{cm}^{-1}$. All operations and the storage of the final product were carried out under purified argon.

The temperature dependent permittivities $\epsilon$, viscosities $\eta$, and densities $d$ of 1-propanol determined by the usual methods of our laboratory ${ }^{(7)}$ are compiled in Table I.

Preparation and/or purification of $\mathrm{NaI}, \mathrm{KI}, \mathrm{KSCN}, \operatorname{Pr}_{4} \mathrm{NI}$, $i$ - $\mathrm{Am}_{3} \mathrm{BuNI}$, and $i-\mathrm{Am}_{3} \mathrm{BuNBPh}_{4}$ is described in Ref. 1 , and of $\mathrm{Bu}_{4} \mathrm{NI}$ and $\mathrm{Bu}_{4} \mathrm{NClO}_{4}$ in Ref. 8 .

$\mathrm{RbI}$ (Merck suprapur) and $\mathrm{NaBr}$ (Merck suprapur) were purified like NaI. Pure $\mathrm{LiCl}$ was prepared by reaction of $\mathrm{Li}$ (Ventron, $99.95 \%$ ) with $\mathrm{HCl}$ (Merck, p.a.). The reaction product was dissolved at $70^{\circ} \mathrm{C}$ in fuming hydrochloric acid (Merck, p.a.) and precipitated from this solution at $-20^{\circ} \mathrm{C}$. After repeated recrystallization (5 times), $\mathrm{LiCl}$ was ground in an argon atmosphere, slowly heated to $500^{\circ} \mathrm{C}$ in a quartz tube furnace under a streaming mixture of pure argon and $\mathrm{HCl}$; from $500{ }^{\circ} \mathrm{C}$ to the melting point of $\mathrm{LiCl}$, the sample was heated under highly pure $\mathrm{HCl}$; cooling down was carried out under increasing argon content of the gas mixture. The final product was stored under pure argon.

$\mathrm{Et}_{4} \mathrm{NI}$ (K\&K Laboratories) was recrystallized four times from methanol-diethyl ether mixtures and dried like $\mathrm{Bu}_{4} \mathrm{NI}{ }^{(8)} n-\mathrm{Am}_{4} \mathrm{NI}$ (Eastman Kodak), $i$-Am ${ }_{4}$ NI (Eastman Kodak), and $n$-Hept ${ }_{4}$ NI (Serva) were five times recrystallized from acetone-diethyl ether mixtures at $-20^{\circ} \mathrm{C}$ and dried at 50 to $60^{\circ} \mathrm{C}$ and $10^{-3} \mathrm{mbar}$ in the presence of SICAPENT (Merck). $\mathrm{Bu}_{3} \mathrm{MeNI}, \mathrm{Bu}_{3} \mathrm{EtNI}$, and $\mathrm{Me}_{2} \mathrm{Bu}_{2} \mathrm{NI}$ were prepared by reaction of the corresponding amines and alkyl iodides: $\mathrm{Bu}_{3} \mathrm{~N}+\mathrm{MeI}$ (water bath, $90^{\circ} \mathrm{C}$ ); $\mathrm{Bu}_{3} \mathrm{~N}+\mathrm{EtI}$ (water bath, $90^{\circ} \mathrm{C}$ ); $\mathrm{MeBu}_{2} \mathrm{~N}+\mathrm{MeI}\left(70^{\circ} \mathrm{C}\right.$ ) (initial products (Fluka), except $\mathrm{MeBu}_{2} \mathrm{~N}$ (K\&K Laboratories)). The reaction products were dissolved in 
ethanol, precipitated by addition of diethyl ether, and repeatedly recrystallized from acetone-diethyl ether mixtures at low temperatures. The purity of the final products was checked by elementary analysis and by their melting points. All operations and the final storage of the purified products under pure argon were carried out with exclusion of light.

The density gradient $D$ for each salt in 1-propanol, needed for the conversion of molonities $\tilde{m}$ [mol-( $\mathrm{kg}$ of solution $\left.)^{-1}\right]$ to molarities $c$ $\left[\mathrm{mol}-\mathrm{dm}^{-3}\right.$ ]

$$
c=\tilde{m} d_{\text {soln }}(T) ; \quad d_{\text {soln }}(T)=d(T)+D \tilde{m} \quad(3 \mathrm{a} \text { and } \mathrm{b})
$$

was determined with the help of a Paar densimeter (DMA 60, DMA $601 \mathrm{HT})$, see Ref. 1. In Eqs. (3), $d_{\text {soln }}(T)$ and $d(T)$ are the densities of the solution and the pure solvent at temperature $T$. The density gradients $D$ were found to be independent of temperature.

The density gradients $D$ and the molar masses $M_{\mathrm{E}}$ of all salts are compiled in Table I.

\subsection{Conductance Measurements}

The conductance measurements were carried out at each molonity under purified argon in temperature cycles through all temperatures of the program, beginning and ending at $25^{\circ} \mathrm{C}$; the $\Lambda-c-T$ diagrams were established by the method given in Refs. 1 and 9. The calibration of the three-electrode conductance cells is based on the temperature dependence of aqueous potassium chloride solutions yielding linear equations of the cell constants vs. temperature. ${ }^{(9)}$ The measured molonities (accuracy: 0.01-0.02\%) and molar conductances (accuracy: $0.01-0.02 \%$ ) are compiled in Table I.

\section{DISCUSSION}

The results of the three $\left(R=R_{1}\right)$ and two parameter $\left(R=R_{1}\right.$ $=R_{2}$, only $i-\mathrm{Am}_{3} \mathrm{BuNBPh}_{4}$ ) fits are reported in Tables III and V. The distance parameters $R_{2}$ from three parameter fits are not relevant for further discussion. Suffice it to mention that $R_{2}$ is found independent of temperature and in agreement with $R$, thus demonstrating the reliability of the method.

A comparative study of two, three, and four parameter fits for various conductance equations and various assumptions on the choice of $R$ can be found in Ref. 7; data analysis for some propanol solutions based on the assumption that $R$ equals the Bjerrum parameter $q$, Eq. 
Table II. Comparison of the Results at $25^{\circ} \mathrm{C}$ with Literature Data*

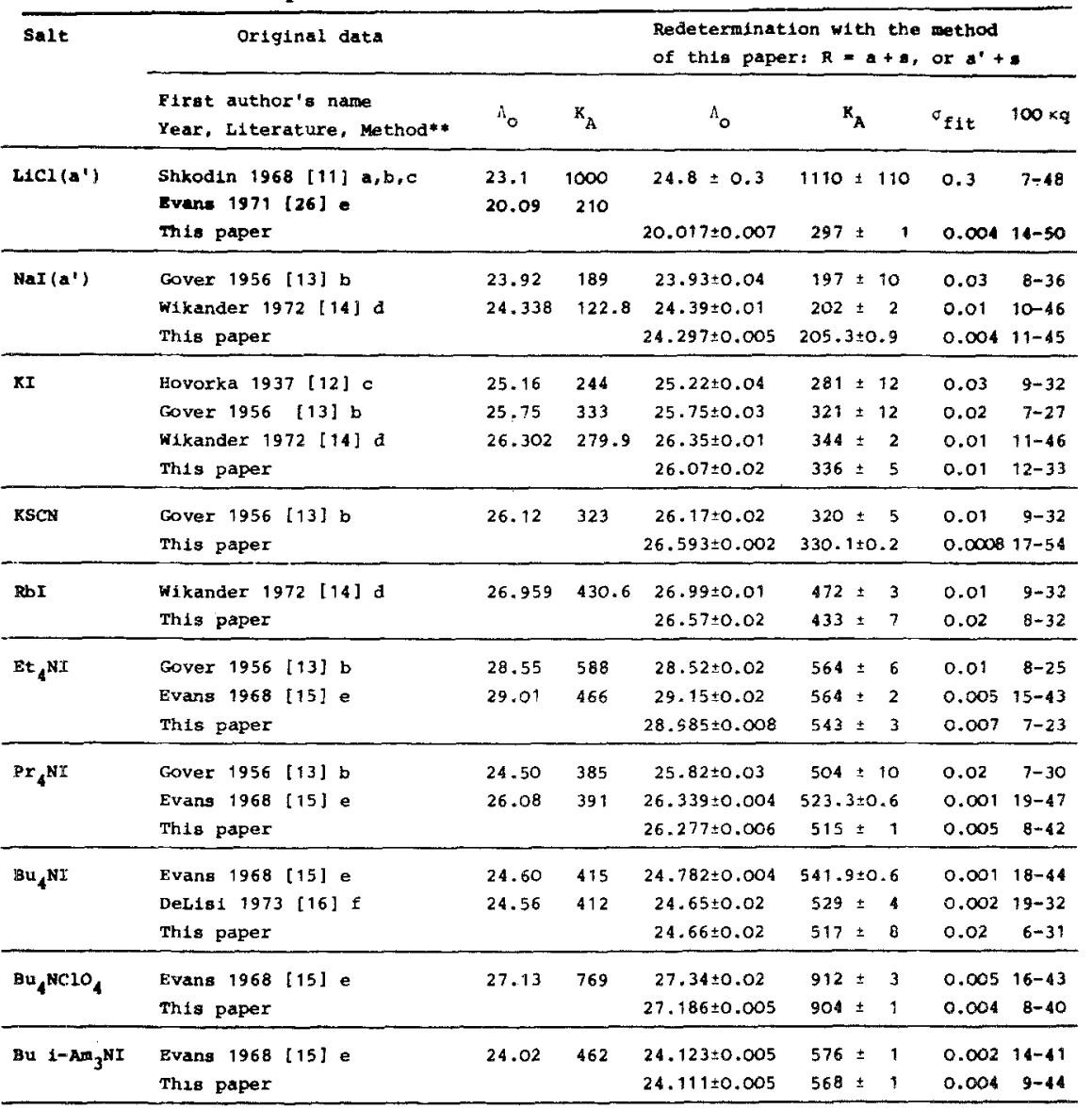

"Units: molar conductance $h, \mathrm{~s}-\mathrm{cm}^{2}-\mathrm{mol}^{-1}$; assoctation constant $\mathrm{K}_{\mathrm{A}}, \mathrm{mol}^{-1}-\mathrm{dm}^{3}$; standard deviation $\sigma_{f i t}, \mathrm{~s}-\mathrm{cm}^{2}-\mathrm{mol}^{-1}$. "Method of data analysis in the ortginal paper: a, Kraus-Bray (J. Am. Chem. soc. 35 (1913) 1315);b, Fuoss-Shedlovsky (J. Am. Chem. Soc. 71 (1949) 1496);C, Fuoss-kraus (J. Am. Chem. Soc. 55 (1933) 476); d, Fuoss-Onsager (J. Phys. Chem. 61 (1957) 668); e, Fuoss-Onsager (R. M. Fuows and F. Accascina, Electrolyte Conductance, Intersc., New York 1959); F, Fuoss-Onsager8kinner (J. Phys. Chem. $\underline{69}$ (1965) 2581).

(2a), is reported in Ref. 10. These studies led us to adopt the standard procedure used in this and preceding papers, see Ref. 1.

The conductance data for 1-propanol solutions at $25^{\circ} \mathrm{C}$ from the literature and from this paper are compared in Table II. For this purpose, limiting conductances $\Lambda_{\mathrm{o}}$ and association constants $K_{\mathrm{A}}$ of the literature were redetermined with the help of $\mathrm{CM}$ calculations as outlined in this paper for the original conductance data which permitted 
Table III. Limiting Conductances of Salts in 1-Propanol from -40 to $25^{\circ} \mathrm{C}^{a}$

\begin{tabular}{|c|c|c|c|c|c|c|c|}
\hline Salt & $25^{\circ} \mathrm{C}$ & $10^{\circ} \mathrm{C}$ & $0^{\circ} \mathrm{C}$ & $-10^{\circ} \mathrm{C}$ & $-20^{\circ} \mathrm{C}$ & $-30^{\circ} \mathrm{C}$ & $-40^{\circ} \mathrm{C}$ \\
\hline $\begin{array}{l}\mathrm{LiCl}\left(\mathrm{a}^{\prime}\right) \\
\mathrm{NaBr}\left(\mathrm{a}^{\prime}\right) \\
\mathrm{NaI}\left(\mathrm{a}^{\prime}\right) \\
\mathrm{KI} \\
\mathrm{KSCN} \\
\mathrm{RbI}\end{array}$ & $\begin{array}{l}20.01_{7} \\
22.65_{3} \\
24.29_{7} \\
26.0_{7} \\
26.59_{3} \\
26.5_{7}\end{array}$ & $\begin{array}{l}13.59_{6} \\
15.47_{0} \\
16.67_{2} \\
17.8_{8} \\
18.26_{6} \\
18.2_{8}\end{array}$ & $\begin{array}{l}10.29_{9} \\
11.76_{4} \\
12.72_{6} \\
13.6_{4} \\
13.943 \\
13.9_{7}\end{array}$ & $\begin{array}{r}7.66_{6} \\
8.78_{9} \\
9.54_{6} \\
10.21_{\epsilon} \\
10.451 \\
10.4_{8}\end{array}$ & $\begin{array}{l}5.59_{1} \\
6.43_{6} \\
7.015 \\
7.49_{7} \\
7.668 \\
7.70_{8}\end{array}$ & $\begin{array}{l}3.98_{4} \\
4.60_{3} \\
5.040 \\
5.37_{4} \\
5.496 \\
5.53_{5}\end{array}$ & $\begin{array}{l}2.760 \\
3.19_{7} \\
3.515 \\
3.73_{9} \\
3.823 \\
3.85_{8}\end{array}$ \\
\hline $\begin{array}{l}\mathrm{Et}_{4} \mathrm{NI} \\
\mathrm{Pr}_{4} \mathrm{NI} \\
\mathrm{Bu}_{4} \mathrm{NI} \\
\mathrm{Bu}_{4} \mathrm{NClO}_{4} \\
n-\mathrm{Am}_{4} \mathrm{NI} \\
i-\mathrm{Am}_{4} \mathrm{NI} \\
\mathrm{Hept}_{4} \mathrm{NI} \\
\mathrm{MeBu}_{3} \mathrm{NI} \\
\mathrm{Me}_{2} \mathrm{Bu}_{2} \mathrm{NI} \\
\mathrm{EtBu}_{3} \mathrm{NI} \\
i-\mathrm{Am}_{3} \mathrm{BuNI} \\
i-\mathrm{Am}_{3} \mathrm{BuN}- \\
\mathrm{BPh}_{4}\end{array}$ & $\begin{array}{l}28.98_{5} \\
26.27_{7} \\
24.6_{6} \\
27.18_{6} \\
23.53_{1} \\
23.78_{8} \\
21.9_{9} \\
25.45_{5} \\
26.56_{2} \\
25.54_{0} \\
24.11_{1} \\
21.0_{5}\end{array}$ & $\begin{array}{l}20.00_{7} \\
18.07_{3} \\
16.9_{6} \\
18.87_{0} \\
16.19_{4} \\
16.35_{5} \\
15.1_{4} \\
17.51_{1} \\
18.27_{6} \\
17.56_{4} \\
16.57_{3} \\
14.5_{1}\end{array}$ & $\begin{array}{l}15.32_{0} \\
13.80_{2} \\
12.9_{6} \\
14.50_{9} \\
12.37_{8} \\
12.49_{2} \\
11.57 \\
13.37_{2} \\
13.96_{9} \\
13.41_{3} \\
12.65_{4} \\
11.0_{9}\end{array}$ & $\begin{array}{r}11.51_{6} \\
10.34_{8} \\
9.71_{4} \\
10.95_{9} \\
9.29_{3} \\
9.36_{8} \\
8.67_{9} \\
10.03_{4} \\
10.47_{9} \\
10.04_{9} \\
9.48_{7} \\
\\
8.3_{1}\end{array}$ & $\begin{array}{l}8.48_{3} \\
7.60_{0} \\
7.13_{4} \\
8.11_{1} \\
6.83_{4} \\
6.88_{4} \\
6.37_{7} \\
7.37_{3} \\
7.70_{4} \\
7.37_{4} \\
6.96_{9} \\
6.0_{7}\end{array}$ & $\begin{array}{l}6.08_{1} \\
5.44_{8} \\
5.11_{6} \\
5.86_{4} \\
4.90_{8} \\
4.93_{8} \\
4.57_{2} \\
5.29_{1} \\
5.52_{7} \\
5.28_{1} \\
4.99_{8} \\
4.32_{4}\end{array}$ & $\begin{array}{l}4.25_{9} \\
3.79_{0} \\
3.56_{1} \\
4.11_{5} \\
3.421 \\
3.43_{9} \\
3.17_{3} \\
3.686 \\
3.84_{8} \\
3.66_{2} \\
3.47_{6} \\
2.97_{3}\end{array}$ \\
\hline
\end{tabular}

Units: $\Lambda_{0}, S-\mathrm{cm}^{2}-\mathrm{mol}^{-1}$.

the use of our programs. The dimensionless quantity $\kappa q$ characterizes the concentration range of the measurements. It is interesting to state that these re-evaluations generally entail better values of $\sigma_{\mathrm{fit}}$ than the original procedures. Comparison is limited by unknown experimental factors, such as purity of the products and protection of the iodides from light, protection of the solutions by an inert gas, and details of the measuring techniques.

Precise determinations of association constants at $25^{\circ} \mathrm{C}$ based on the chemical model are known from calorimetric measurements of heats of dilution ${ }^{(17)}\left(K_{\mathrm{A}}, \mathrm{mol}^{-1}-\mathrm{dm}^{3}\right): 314(\mathrm{NaBr}), 206(\mathrm{NaI}), 374(\mathrm{KI})$, $527(\mathrm{RbI}), 535\left(\mathrm{Et}_{4} \mathrm{NI}\right), 513\left(\mathrm{Pr}_{4} \mathrm{NI}\right), 534\left(\mathrm{Bu}_{4} \mathrm{NI}\right), 536\left(n-\mathrm{Am}_{4} \mathrm{NI}\right), 581$ $\left(i-\mathrm{Am}_{4} \mathrm{NI}\right), 597\left(\mathrm{MeBu}_{3} \mathrm{NI}\right), 691\left(\mathrm{Me}_{2} \mathrm{Bu}_{2} \mathrm{NI}\right), 535\left(\mathrm{EtBu}_{3} \mathrm{NI}\right)$, and 559 $\left(i-\mathrm{Am}_{3} \mathrm{BuNI}\right)$. The results of these measurements are compared to our conductance data in Section 3.2. Suffice it to say here that the agreement of the association constants at $25^{\circ} \mathrm{C}$ from calorimetric and conductance measurements, Tables II and $\mathrm{V}$, is satisfactory. 
Table IV. Limiting Ionic Conductances for 1-Propanol Solutions at 25 and $10^{\circ} \mathrm{C}^{a}$

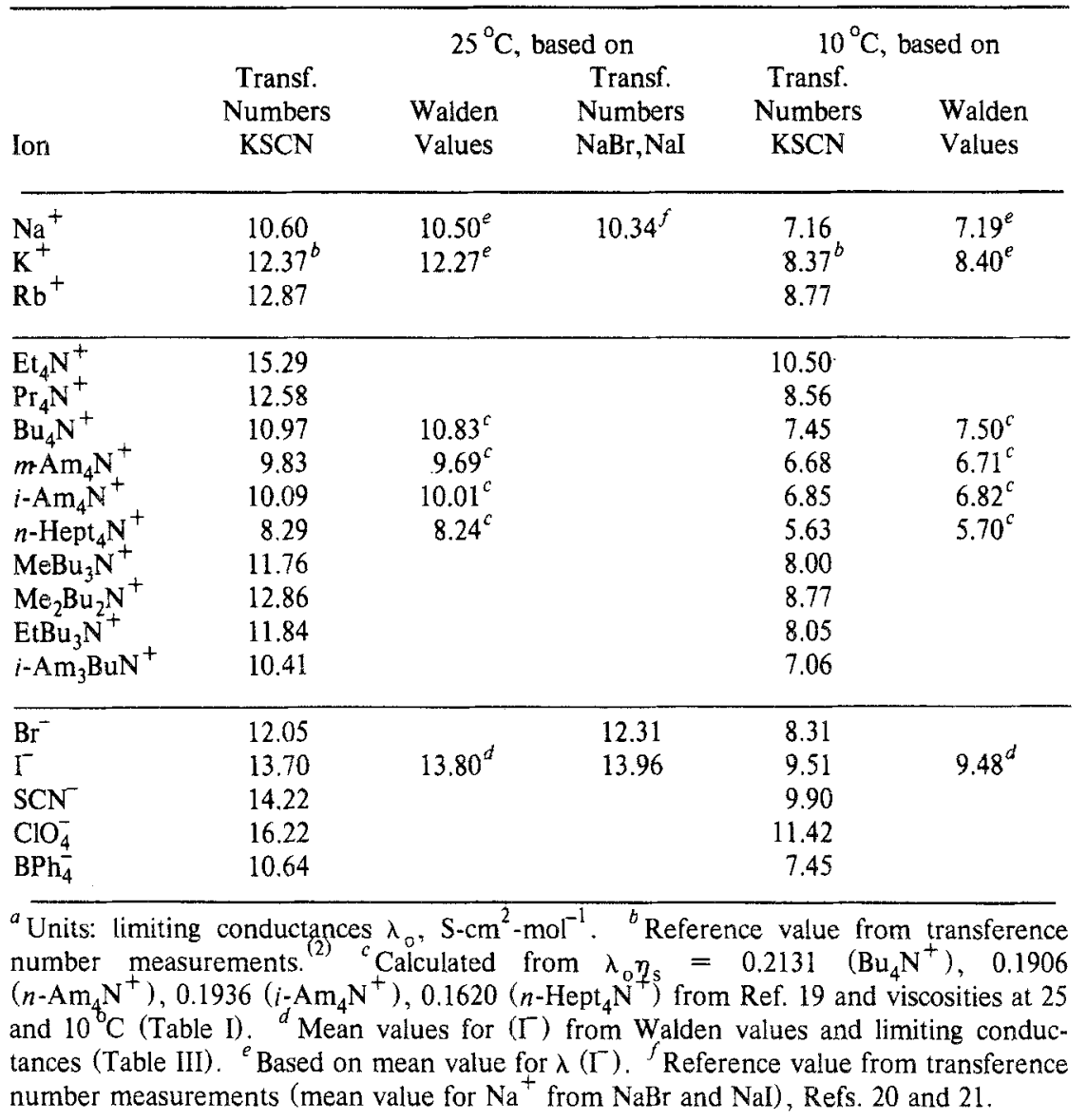

\subsection{Limiting Conductances}

Table III shows the limiting conductance results from the data analysis described above. Alternative evaluations of $\Lambda_{0}$ for lithium and sodium salts based on the assumption $R=a+s$ (instead of $R=a^{\prime}$ $+s$, Table III) didn't show significant difference, as expected from our studies on ethanol solutions. ${ }^{(1)}$

Transference numbers of KSCN in 1-propanol are known at 25 and $10{ }^{\circ} \mathrm{C}:^{(2)} t_{0}^{+}\left(25^{\circ} \mathrm{C}\right)=0.4654 \pm 0.0005$ and $t_{0}^{+}\left(10^{\circ} \mathrm{C}\right)=0.4583$ 


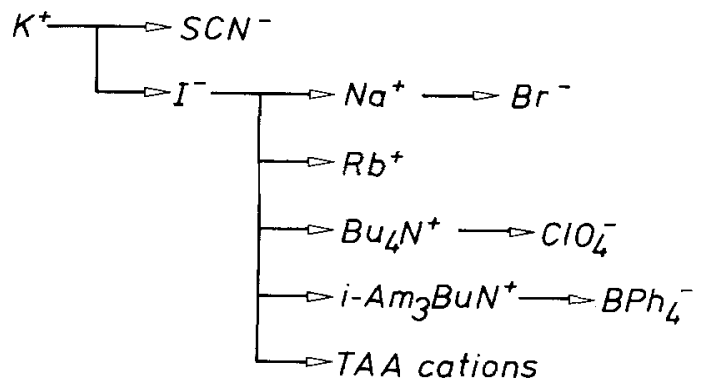

Fig. 1. Flow diagram for the calculation of the limiting ionic conductances from transference numbers of $\mathrm{KSCN}$ in 1-propanol at 25 and $10^{\circ} \mathrm{C}$ given in Table IV.

\pm 0.0015 . They were used for the calculation of limiting conductances in Table IV, columns 1 and 4, following the scheme of Fig. 1.

Columns 2 and 5, Table IV, show single ion conductances which were independently determined from Walden values. This method is known to produce reasonably well approximated data for voluminous organic ions in various nonaqueous solvents; ${ }^{(18)}$ the reference data for $\mathrm{Bu}_{4} \mathrm{~N}^{+}, n-\mathrm{Am}_{4} \mathrm{~N}^{+}, i-\mathrm{Am}_{4} \mathrm{~N}^{+}$, and $n-\mathrm{Hept}_{4} \mathrm{~N}^{+}$were used to calculate the mean value of $\lambda_{0}\left(\mathrm{I}^{-}\right)$with the help of the limiting conductances of the corresponding tetraalkylammonium iodide conductances of Table III. Similar methods were used by Evans and Gardam $\left(i-\mathrm{Am}_{3} \mathrm{BuN}^{+}\right.$ and $n$-Hex $\left.{ }_{4} \mathrm{~N}^{+}\right)^{(15)}$ and De Lisi and Goffredi $\left(\mathrm{Bu}_{4} \mathrm{~N}^{+}\right),{ }^{(16)}$ their values are in reasonable agreement with Table IV. Gill ${ }^{(22)}$ used the equipartition of $\Lambda_{0}\left(\mathrm{Bu}_{4} \mathrm{NBBu}_{4}\right)$ into equal parts for anion and cation to yield $\lambda_{0}\left(\mathrm{Bu}_{4} \mathrm{~N}^{+}\right)=10.51 \mathrm{~S}-\mathrm{cm}^{2}-\mathrm{mol}^{-1}$ [from $\Lambda_{0}=(21.01 \pm 0.10)$ after reevaluation of Gill's data according to the CM]. The limiting conductances of Marx et al. ${ }^{(20,21)}$ are quoted in Table IV, column 3. They are based on transference numbers of $\mathrm{NaI}$ and $\mathrm{NaBr}$ in 1-propanol solutions using $\mathrm{Co}^{2+}$ as boundary indicator. Wikander and Isacsson ${ }^{(14)}$ used the transference numbers of alkali metal ions in ethanol also for 1propanol solutions claiming a precision of about $2 \%$. This claim is justified by our determination of the cation transference numbers of KSCN in ethanol and 1-propanol by a moving boundary method, ${ }^{(2)}$ $t_{0}\left(\mathrm{~K}^{+}, \mathrm{EtOH}\right)=0.4590 \pm 0.0003$ and $t_{0}\left(\mathrm{~K}^{+}, \mathrm{PrOH}\right)=0.4654 \pm 0.0005$.

Comparison of $\lambda_{0}\left[i-\mathrm{Am}_{3} \mathrm{BuN}^{+}\right]$and $\lambda_{0}\left[\mathrm{BPh}_{4}^{-}\right]$indicates that splitting of $\Lambda_{0}\left[i-\mathrm{Am}_{3} \mathrm{BuNBPh}_{4}\right]$ into equal contributions for cation and anion in 1-propanol solutions $\left(2 \%\right.$ difference at $25^{\circ} \mathrm{C}, 6 \%$ at $\left.10^{\circ} \mathrm{C}\right)$ is more favorable than in ethanol solutions $\left(7 \%\right.$ at $25^{\circ} \mathrm{C}, 8 \%$ at $\left.-5^{\circ} \mathrm{C}\right) .{ }^{(1)}$

Taking into account the possible uncertainties and sources of error, our data at $25^{\circ} \mathrm{C}$ (column 1) and $10^{\circ} \mathrm{C}$ (column 4) show a preci- 
sion of about $1 \%$ or better.

The slopes at $25{ }^{\circ} \mathrm{C}, \mathrm{d}\left(\ln \lambda_{0}\right) / \mathrm{d}(1 / T)$, for all cations are found to be $(-2.17 \pm 0.05) \times 10^{3}$, and for all anions within $(-2.05 \pm 0.04) \times 10^{3}$, viscosity data of pure 1 -propanol yield $-\mathrm{d}\left(\ln \eta_{\mathrm{s}}\right) / \mathrm{d}(1 / T)=-2.1 \times 10^{3}$, again indicating that the activation energies of ionic transport do not vary significantly for ions of different size, $c f$. Ref. 1 , and are comparable to the activation energy of viscous flow of the solvent, $c f$. Ref. 8.

Positive slopes of the Walden products, $\mathrm{d}\left(\ln \eta_{\mathrm{s}} \lambda_{0}\right) / \mathrm{d} T$, are found for the cations, negative or zero slopes for the anions which might be interpreted in terms of structure promoting or breaking ionic effects. ${ }^{(23-25)}$

\subsection{Association Constants}

The association constants $K_{\mathrm{A}}$ for all salts are quoted in Table

Table V. Association Constants for Salts in 1-Propanol in the

Temperature Range -45 to $25^{\circ} \mathrm{C}{ }^{a}$

\begin{tabular}{llllllll}
\hline Salt & $25{ }^{\circ} \mathrm{C}$ & $10{ }^{\circ} \mathrm{C}$ & $0{ }^{\circ} \mathrm{C}$ & $-10{ }^{\circ} \mathrm{C}$ & $-20{ }^{\circ} \mathrm{C}$ & $-30{ }^{\circ} \mathrm{C}$ & $-40{ }^{\circ} \mathrm{C}$ \\
\hline $\mathrm{LiCl}\left(\mathrm{a}^{\prime}\right)$ & $2.9_{7}$ & $2.0_{0}$ & $1.58_{9}$ & $1.29_{4}$ & $1.07_{3}$ & $0.90_{9}$ & $0.79_{3}$ \\
$\mathrm{NaBr}\left(\mathrm{a}^{\prime}\right)$ & 3.08 & 2.13 & $1.71_{0}$ & $1.42_{4}$ & $1.21_{0}$ & $1.05_{0}$ & $0.94_{0}$ \\
$\mathrm{NaI}\left(\mathrm{a}^{\prime}\right)$ & $2.05_{3}$ & $1.50_{6}$ & $1.26_{5}$ & $1.08_{7}$ & $0.94_{3}$ & $0.85_{1}$ & $0.76_{8}$ \\
$\mathrm{KI}(\mathrm{a})$ & $3.3_{6}$ & $2.3_{5}$ & $1.9_{0}$ & $1.5_{6}$ & $1.2_{9}$ & $1.0_{9}$ & $0.9_{1}$ \\
$\mathrm{KSCN}(\mathrm{a})$ & 3.301 & 2.373 & 1.949 & 1.627 & 1.365 & 1.164 & 1.000 \\
$\mathrm{RbI}(\mathrm{a})$ & $4.3_{3}$ & $3.1_{1}$ & $2.5_{4}$ & $2.1_{0}$ & $1.7_{5}$ & $1.4_{8}$ & $1.2_{4}$ \\
\hline $\mathrm{Et}_{4} \mathrm{NI}$ & $5.4_{3}$ & $4.9_{2}$ & $4.7_{2}$ & $4.5_{8}$ & $4.5_{8}$ & 4.7 & $4.7_{8}$ \\
$\mathrm{Pr}_{4} \mathrm{NI}$ & $5.1_{5}$ & $4.73_{0}$ & $4.58_{8}$ & $4.53_{5}$ & $4.5_{7}$ & $4.6_{7}$ & $4.8_{6}$ \\
$\mathrm{Bu}_{4} \mathrm{NI}$ & $5.1_{7}$ & $4.7_{7}$ & $4.6_{4}$ & $4.5_{5}$ & $4.5_{8}$ & $4.6_{7}$ & $4.8_{3}$ \\
$\mathrm{Bu}_{4} \mathrm{NClO}{ }_{4}$ & $9.0_{4}$ & $8.8_{9}$ & $9.0_{2}$ & $9.3_{3}$ & $9.8_{5}$ & $10.6_{2}$ & $11.6_{4}$ \\
$n-\mathrm{Am}_{4} \mathrm{NI}$ & $5.3_{7}$ & $4.9_{9}$ & $4.87_{6}$ & $4.85_{2}$ & $4.89_{8}$ & $5.0_{1}$ & $5.2_{3}$ \\
$i-\mathrm{Am}_{4} \mathrm{NI}$ & $5.7_{3}$ & $5.3_{5}$ & $5.2_{3}$ & $5.2_{1}$ & $5.2_{7}$ & $5.4_{2}$ & $5.6_{7}$ \\
$\mathrm{Hept}_{4} \mathrm{NI}$ & $5.0_{9}$ & $4.6_{5}$ & $4.4_{6}$ & $4.3_{6}$ & $4.2_{8}$ & $4.2_{3}$ & $4.1_{4}$ \\
$\mathrm{MeBu}_{3} \mathrm{NI}$ & $6.0_{7}$ & $5.5_{6}$ & $5.3_{6}$ & $5.29_{6}$ & $5.3_{1}$ & $5.4_{4}$ & $5.69_{0}$ \\
$\mathrm{Me}_{2} \mathrm{Bu}{ }_{2} \mathrm{NI}$ & $6.6_{5}$ & $6.0_{1}$ & $5.7_{9}$ & $5.6_{7}$ & $5.6_{6}$ & $5.7_{6}$ & $5.9_{6}$ \\
$\mathrm{EtBu}_{3} \mathrm{NI}$ & $5.41_{3}$ & $4.95_{4}$ & $4.7_{9}$ & $4.7_{0}$ & $4.6_{6}$ & $4.7_{2}$ & $4.8_{0}$ \\
$i-\mathrm{Am}_{3} \mathrm{BuNI}$ & $5.6_{8}$ & $5.2_{8}$ & $5.1_{5}$ & $5.1_{2}$ & $5.1_{6}$ & $5.2_{9}$ & $5.5_{0}$ \\
$i-\mathrm{Am}_{3} \mathrm{BuN}$ & 6.1 & $7 . ._{0}$ & 7.8 & 8.9 & 10.1 & 11.5 & 13.4 \\
$\mathrm{BPh}_{4}$ & & & & & & & \\
\end{tabular}

$a$ All constants are given as values of $K_{\mathrm{A}} \times 10^{-2}$. Units: $K_{\mathrm{A}^{\prime}} \mathrm{mol}^{-1}-\mathrm{dm}^{3}$. 
V. CM calculations suggest the interpretation of association constants by the help of the relationship (cgs units). ${ }^{(1,3)}$

$$
K_{\mathrm{A}}=4 \pi N_{\mathrm{A}} \times 10^{-3} \exp \left[-\frac{\Delta G^{*}}{R T}\right] \int_{a \text { or } a^{\prime}}^{R} r^{2} \exp \left[\frac{2 q}{r}\right] \mathrm{d} r
$$

where $\Delta G^{*}=N_{\mathrm{A}} W_{+-}^{*} ; W_{+-}^{*}$ is that part of the potential of the mean forces between cations and anions which is due to the non-coulombic interactions ${ }^{(3)}$

$$
\begin{array}{ll}
W_{+-}^{*}=\text { constant, } & \text { if } a \text { or } a^{\prime} \leqslant r \leqslant R \\
W_{+-}^{*}=0, & \text { if } r \geqslant R
\end{array}
$$

The other symbols of Eq. (4) have their usual meaning.

In Eq. (4), $a^{\prime}$ is the distance of closest approach between cation and anion in the solution given by the configuration $\left[\mathrm{C}^{+}(\mathrm{OH}) \mathrm{A}^{-}\right]$for lithium and sodium salts and $a$ is the cation-anion distance of the contact pair $\left[\mathrm{C}^{+} \mathrm{A}^{-}\right]$used for all other salts, $R$ is given by the configurations $\left[\mathrm{C}^{+}(\mathrm{OH})\left(\mathrm{C}_{3} \mathrm{H}_{7} \mathrm{OH}\right) \mathrm{A}^{-}\right]$and $\left[\mathrm{C}^{+}\left(\mathrm{C}_{3} \mathrm{H}_{7} \mathrm{OH}\right) \mathrm{A}^{-}\right]$, respectively.

Alkali metal and tetraalkylamonium salts exhibit quite different $K_{\mathrm{A}}$ behavior as shown in Figs. 2 and 3, in complete agreement with the results on ethanol solutions. ${ }^{(1)}$ Alkali metal salts show association constants which increase at increasing temperatures, whereas those for tetraalkylammonium salts show shallow minima, except $i-\mathrm{Am}_{3} \mathrm{BuNBPh}_{4}$ which shows a negative temperature coefficient, $\mathrm{d} K_{\mathrm{A}} / \mathrm{d} T<0$. The temperature at which the minimum is attained is almost equal for the tetraalkylammonium iodides (except $\mathrm{Hept}_{4} \mathrm{NI}$ ); it is significantly shifted to higher values with increasing anion size for $\mathrm{Bu}_{4} \mathrm{NClO}_{4}$ and $i$ - $\mathrm{Am}_{3} \mathrm{BuNBPh}_{4}$. These results are independent of the choice of $R$ within reasonable limits.

As was the case for ethanol solutions, the different behavior of alkali metal and tetraalkylammonium salts can be understood from the role of the non-coulombic contributions in ion-pair formation. The Gibbs' energy of ion-pair formation

$$
\Delta G_{\mathrm{T}}^{\mathrm{o}}=-R T \ln K_{\mathrm{A}}
$$

can be split into two parts

$$
\Delta G_{\mathrm{T}}^{\circ}=\Delta G^{\mathrm{coul}}+\Delta G^{*}
$$

according to Eq. (4). The molarity scale is used throughout for the fol- 


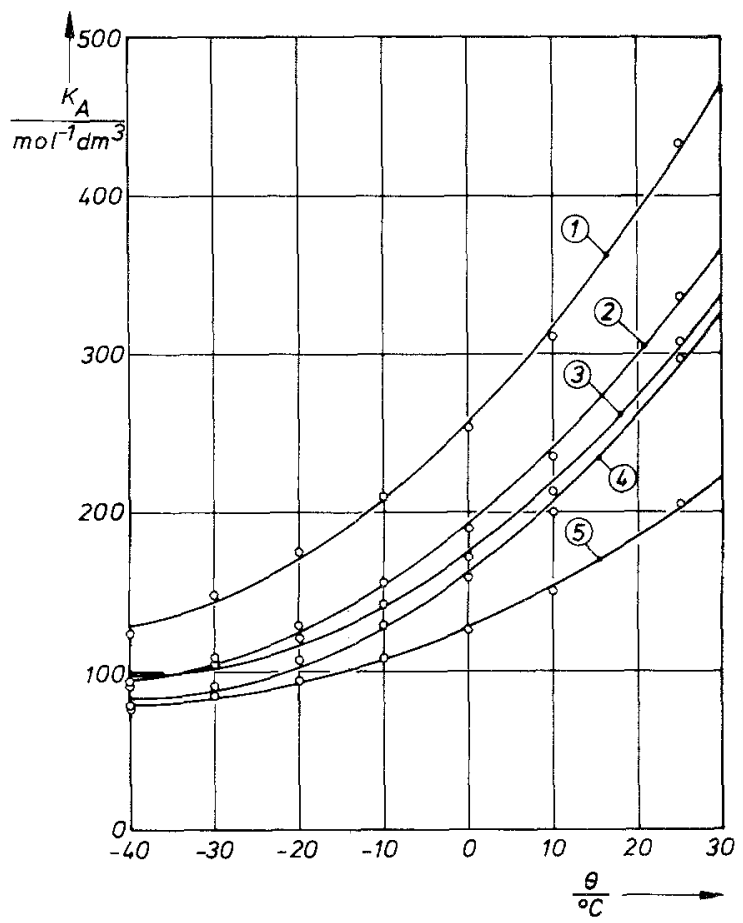

Fig. 2. Temperature dependence of the association constants of alkali metal salts in 1-propanol solutions; RbI (1), KI (2), NaBr (3), $\mathrm{LiCl}(4)$, and $\mathrm{NaI}(5)$.

lowing calculations; conversion into the molality scale can be done easily, ${ }^{(1)}$ but doesn't change the features of our discussion.

Table VI compiles the coefficients $A_{0}, A_{1}$, and $A_{2}$ of the following polynomials calculated from the temperature dependence of $K_{\mathrm{A}}$

$$
\begin{aligned}
\Delta G_{\mathrm{T}}^{\mathrm{o}} & =A_{0}+A_{1}(298.15-T)+A_{2}(298.15-T)^{2} \\
\Delta S_{\mathrm{T}}^{\mathrm{o}} & =A_{1}+2 A_{2}(298.15-T) \\
\Delta H_{\mathrm{T}}^{\mathrm{o}} & =A_{0}+298.15 A_{1}+A_{2}\left[(298.15)^{2}-T^{2}\right]
\end{aligned}
$$

$\Delta H_{\mathrm{T}}^{\circ}$ and $\Delta S_{\mathrm{T}}^{\circ}$ are the enthalpy and entropy of ion-pair formation.

The values of $\Delta G_{\mathrm{T}}^{\circ}, \Delta H_{\mathrm{T}}^{\circ}$, and $\Delta S_{\mathrm{T}}^{\circ}$ at $25^{\circ} \mathrm{C}$ then are

$$
\Delta G_{298}^{\circ}=A_{0} ; \quad \Delta S_{298}^{\circ}=A_{1} ; \quad \Delta H_{298}^{\circ}=A_{0}+298.15 A_{1}(8 \mathrm{a}, \mathrm{b}, \text { and c })
$$

As usual, the values of $\Delta G_{298}^{o}$ provide no useful information on ion-pair 


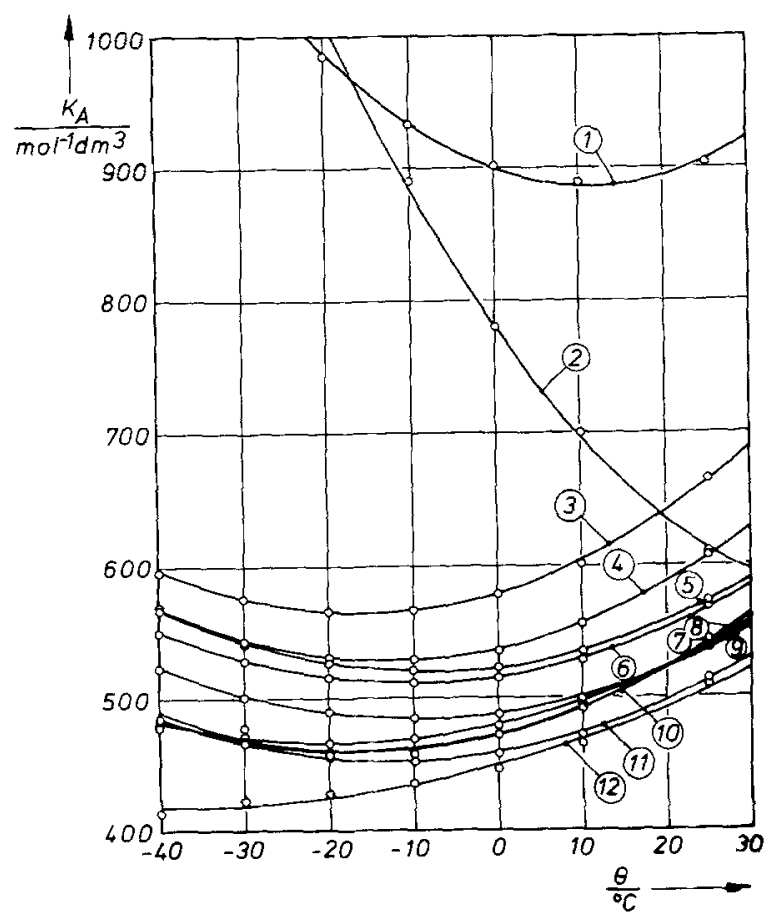

Fig. 3. Temperature dependence of the association constants of tetraalkylammonium salts in 1-propanol solutions: $\mathrm{Bu}_{4} \mathrm{NClO}_{4}(1), i-\mathrm{Am}_{3} \mathrm{BuNBPh}_{4}(2), \mathrm{Me}_{2} \mathrm{Bu}_{2} \mathrm{NI}(3), \mathrm{MeBu}_{3} \mathrm{NI}$ (4), $i-\mathrm{Am}_{4} \mathrm{NI}$ (5), $i-\mathrm{Am}_{3} \mathrm{BuNI}$ (6), $\mathrm{Et}_{4} \mathrm{NI}$ (7), $\mathrm{Pr}_{4} \mathrm{NI}(8), \mathrm{EtBu}_{3} \mathrm{NI}$ (9), $n$-Am 4 NI (10), $\mathrm{Bu}_{4} \mathrm{NI}(11)$, and $\mathrm{Hept}_{4} \mathrm{NI}(12)$.

formation. They lie between -13 and $-17 \mathrm{~kJ}^{-\mathrm{mol}^{-1}}$ for both alkali metal and tetraalkylammonium salts. The values of $\Delta S_{298}^{\circ}$ and $\Delta H_{298}^{\circ}$, however, exhibit a significant pattern. Alkali metal salts show entropy values around their mean value of $106 \mathrm{~J}-\mathrm{mol}^{-1}-\mathrm{K}^{-1}$, tetraalkylammonium salts around $67 \mathrm{~J}-\mathrm{mol}^{-1}-\mathrm{K}^{-1}$, with the exception of $i$ - $\mathrm{Am}_{3} \mathrm{BuNBPh}_{4}$. The $\Delta H_{298}^{0}$ values of alkali metal salts are all about $17.5 \mathrm{~kJ}-\mathrm{mol}^{-1}$. Tetraalkylammonium salts show enthalpies less than 5; the shift of the minima, Fig. 3, to higher temperatures in the sequence $\mathrm{I}^{-}<\mathrm{ClO}_{4}^{-}<\mathrm{BPh}_{4}^{-}$is reflected in Table VI by decreasing enthalpies. It might be interesting (although of minor importance) to mention that the tetraalkylammonium iodides of the type $R_{n} R_{4-n}^{\prime} N I$ exhibit an empirical rule given by the relationship

$$
\Delta H_{298}^{\circ}\left(\mathrm{R}_{n} \mathrm{R}_{4-n}^{\prime} \mathrm{NI}\right)=1 / 4\left[n \Delta H_{298}^{\circ}\left(\mathrm{R}_{4} \mathrm{NI}\right)+(4-n) \Delta H_{298}^{\circ}\left(\mathrm{R}_{4}^{\prime} \mathrm{NI}\right)\right]
$$

e.g., for $i-\mathrm{Am}_{3} \mathrm{BuNI}$ the observed (Table VI) and estimated [Eq. (9)] 
Table VI. Coefficients of Polynomials in Eq. (7a) for Various Salts in 1-Propanol ${ }^{a, b}$

\begin{tabular}{|c|c|c|c|c|c|}
\hline Salt & $A_{\mathrm{o}}{ }^{c}$ & $A_{1}{ }^{d}$ & $A_{2}$ & $\sigma_{\text {fit }}$ & $\begin{array}{c}A_{\mathrm{o}}{ }^{+} \\
298.15 A_{1}{ }^{e}\end{array}$ \\
\hline $\mathrm{LiCl}\left(\mathrm{a}^{\prime}\right)$ & -14102.4 & 113.923 & -0.422597 & 10.3 & 19863.7 \\
\hline $\operatorname{NaBr}\left(\mathrm{a}^{\prime}\right)$ & -14195.2 & 110.831 & -0.431488 & 10.8 & 18849.1 \\
\hline $\mathrm{NaI}\left(\mathrm{a}^{\prime}\right)$ & -13188.3 & $96.56 ? 0$ & -0.359159 & 16.6 & 15603.2 \\
\hline KI & -14409.9 & 107.215 & -0.313094 & 16.8 & 17556.3 \\
\hline $\mathrm{KSCN}$ & -14367.1 & 102.809 & -0.296483 & 12.8 & 16285.4 \\
\hline RbI & -15038.2 & 105.031 & -0.271307 & 15.0 & 16276.8 \\
\hline $\mathrm{Et}_{4} \mathrm{NI}$ & -15599.4 & 70.0512 & -0.223141 & 30.5 & 5286.4 \\
\hline $\mathrm{Pr}_{4} \mathrm{NI}$ & -15472.7 & 67.2109 & -0.212260 & 11.3 & 4566.2 \\
\hline $\mathrm{Bu}_{4} \mathrm{NI}$ & -15480.7 & 66.4499 & -0.195453 & 9.7 & 4331.3 \\
\hline $\mathrm{Bu}_{4} \mathrm{NClO}_{4}$ & -16867.2 & 61.0904 & -0.188731 & 9.7 & 1346.9 \\
\hline$n-\mathrm{Am}_{4} \mathrm{NI}$ & -15574.2 & 65.2114 & -0.190927 & 10.5 & 3868.6 \\
\hline$i-\mathrm{Am}_{4} \mathrm{NI}$ & -15736.1 & 65.3807 & -0.191760 & 9.5 & 3757.2 \\
\hline$n$-Hept ${ }_{4}$ NI & -15434.6 & 65.5441 & -0.124236 & 21.4 & 4107.4 \\
\hline $\mathrm{MeBu}_{3} \mathrm{NI}$ & -15881.2 & 69.7741 & -0.226655 & 8.7 & 4921.9 \\
\hline $\mathrm{Me}_{2} \mathrm{Bu}_{2} \mathrm{NI}$ & -16101.0 & 71.7304 & -0.226477 & 12.1 & 5285.4 \\
\hline $\mathrm{EtBu}_{3} \mathrm{NI}$ & -15593.1 & 67.4863 & -0.183177 & 12.8 & 4527.9 \\
\hline$i-\mathrm{Am}_{3} \mathrm{BuNI}$ & -15713.5 & 65.7599 & -0.189400 & 10.8 & 3892.8 \\
\hline$i-\mathrm{Am}_{3} \mathrm{BuNBPh}_{4}$ & -15896.7 & 30.6883 & -0.152435 & 15.0 & -6747.0 \\
\hline
\end{tabular}

${ }^{a}$ Units: $\Delta G_{\mathrm{T}}^{\circ}, \mathrm{J}-\mathrm{mol}^{-1} .{ }^{b}$ The numerical results in this table are not limited to significant numbers, thus permitting the reproduction of measurements with the original precision. ${ }^{c} A_{0}=\Delta G_{298}^{0}, \mathrm{~J}-\mathrm{mol}^{-1} \cdot{ }^{d} A_{1}=\Delta S_{298}^{0}, \mathrm{~J}-\mathrm{mol}^{-1}-\mathrm{K}^{-1} \cdot{ }^{e} A_{\mathrm{o}}+298.15 A_{1}=\Delta H_{298}^{\circ}$, $\mathrm{J}-\mathrm{mol}^{-1}$

$\Delta H_{298}^{\circ}$ values are 3.9 and 4.0, respectively; the enthalpy of ion-pair formation for $\mathrm{Et}_{4} \mathrm{NI}$ is estimated to be 5.2 from $\mathrm{EtBu}_{3} \mathrm{NI}$ in comparison to 5.3, Table VI.

The difference between the mean value of the tetraalkylammonium salts and $i-\mathrm{Am}_{3} \mathrm{BuNBPh}_{4}$ in $\Delta S_{298}^{\circ}$ is $35 \mathrm{~J}-\mathrm{mol}^{-1}-\mathrm{K}^{-1}$, and in $\Delta H_{298}^{0}$ is $11 \mathrm{~kJ}^{-\mathrm{mol}^{-1}}$. This is exactly the same pattern which was observed for ethanol solutions. Again, the difference in $\Delta H_{298}^{\circ}$ and $\Delta S_{298}^{\circ}$ for alkali metal and tetraalkylammonium salts, and the almost equal decrease with regard to the other tetraalkylammonium salts produced by the tetraphenylborate ion, indicate that replacing a solvated cation or anion by an unsolvated species entails about the same effect on the non-coulombic parts of the mean force potentials.

For ethanol solutions, we published the scales of $\Delta H^{*}\left(\mathrm{~kJ}-\mathrm{mol}^{-1}\right)$ and $\Delta S^{*}\left(\mathrm{~J}-\mathrm{mol}^{-1}-\mathrm{K}^{-1}\right)$ values. ${ }^{(1)}$ The corresponding scales for 1 - 
propanol solutions also exhibit $\mathrm{LiCl}$ at the highest $\left(\Delta S_{298}^{*}=47, \Delta H_{298}^{*}\right.$ $=11.6)$ and $i-\mathrm{Am}_{3} \mathrm{BuNBPh}_{4}$ at the lowest $\left(\Delta S_{298}^{*}=-21, \Delta H_{298}^{*}=\right.$ -11.7) places. The other tetraalkylammonium salts show small values of $\Delta S_{298}^{*}$ around 6 and negative enthalpies, $\Delta H_{298}^{*}<-2$. The alkali metal salts exhibit distinctly larger entropies, $\Delta S_{298}^{*}>20$, and positive enthalpies, $\Delta H_{298}^{*}>4$. Hence, the main features of association are equal both in ethanol and 1-propanol and do not need repeated discussion for 1-propanol solutions.

Heat of dilution measurements at $25^{\circ} \mathrm{C}$ yield $K_{\mathrm{A}}$ and $\Delta H_{298}^{\circ}$ by $\mathrm{CM}$ calculations ${ }^{(17)}$ and hence also $\Delta S_{298}^{\circ}$. Table VII compares the results from such calorimetric measurements and the conductance data of this paper.

Table VII. Comparison of Enthalpies and Entropies of Ion-Pair Formation from Heat of Dilution (Ref. 17) and Conductance (this Paper) ${ }^{a}$

\begin{tabular}{|c|c|c|c|c|c|c|}
\hline \multirow[b]{2}{*}{ Electrolyte } & \multicolumn{3}{|c|}{ Heat of Dilution ${ }^{b, c}$} & \multicolumn{3}{|c|}{ Conductance } \\
\hline & $R$ & $\Delta H_{298}^{\circ}$ & $\Delta S_{298}^{\circ}$ & $R$ & $\Delta H_{298}^{\mathrm{o}}$ & $\Delta S_{298}^{\circ}$ \\
\hline \multirow[t]{2}{*}{$\mathrm{NaBr}$} & & & & 12.7 & 18.8 & 111 \\
\hline & 9.2 & 22.1 & 122 & $\begin{array}{l}(9.2) \\
120\end{array}$ & $\begin{array}{c}(20.3) \\
156\end{array}$ & $\begin{array}{c}(115) \\
97\end{array}$ \\
\hline $\mathrm{Nal}$ & 9.7 & 18.9 & 107 & (9.7) & $(17.2)$ & (101) \\
\hline \multirow[t]{2}{*}{ KI } & & & & 10.4 & 17.6 & 107 \\
\hline & 9.9 & 19.1 & 113 & (9.9) & (18.1) & (109) \\
\hline \multirow[t]{2}{*}{$\mathrm{RbI}$} & & & & 10.6 & 16.2 & 105 \\
\hline & 9.5 & 17.5 & 111 & (9.5) & $(16.5)$ & (106) \\
\hline $\mathrm{Et}_{4} \mathrm{NI}$ & 13.1 & 6.6 & 75 & 13.1 & 5.3 & 70 \\
\hline $\mathrm{Pr}_{4}^{4} \mathrm{NI}$ & 13.6 & 6.0 & 72 & 13.6 & 4.6 & 67 \\
\hline $\mathrm{Bu}_{4}^{4} \mathrm{NI}$ & 14.0 & 5.7 & 71 & 14.0 & 4.3 & 66 \\
\hline$n-\mathrm{Am}_{4} \mathrm{NI}$ & 14.4 & 5.6 & 71 & 14.4 & 3.9 & 65 \\
\hline$i-\mathrm{Am}_{4} \mathrm{NI}$ & 14.1 & 5.2 & 70 & 14.1 & 3.8 & 65 \\
\hline $\mathrm{MeBu}_{3} \mathrm{NI}$ & 12.6 & 6.4 & 75 & 12.6 & 4.9 & 70 \\
\hline $\mathrm{Me}_{2} \mathrm{Bu}_{2}^{3} \mathrm{NI}$ & 12.6 & 7.0 & 78 & 12.6 & 5.3 & 72 \\
\hline $\mathrm{EtBu}_{3} \mathrm{NI}^{2}$ & 13.1 & 5.9 & 72 & 13.1 & 4.5 & 68 \\
\hline$i-\mathrm{Am}_{3} \mathrm{BuNI}$ & 14.1 & 5.3 & 71 & 14.1 & 3.9 & 66 \\
\hline
\end{tabular}

${ }^{a}$ Units: $R, \mathrm{~A} ; \Delta H_{298}^{0}, \mathrm{~kJ}^{-\mathrm{mol}^{-1} ; \Delta S_{298}^{0}, \mathrm{~J}-\mathrm{mol}^{-1}-\mathrm{K}^{-1} \text {. }{ }^{b} \text { Distance parameters } R \text { for alkali }}$ metal salts from least squares fits of calorimetric measurements; $R$ for tetraalkylammonium salts is $a+s$ ( $c f$. conductance measurements). ' $D$ ata analysis of tetraalkylammonium salts includes an empirical $\mathrm{m}^{3 / 2}$ term which is not given by the chemical model. 
The agreement of the association constants $K_{\mathrm{A}}$ from both methods was shown in Chapter 3 . Both methods also yield comparable values of $\Delta H_{298}^{\circ}$ and $\Delta S_{298}^{\circ}$. In Table VII, columns $2(\mathrm{R}), 3\left(\Delta H_{\mathrm{A}}^{\circ}\right)$, and $4\left(\Delta S_{\mathrm{A}}^{0}\right)$ show the results from calorimetric, ${ }^{(17)}$ and columns $5(\mathrm{R})$, $6\left(\Delta H_{298}^{\circ}\right)$, and $7\left(\Delta S_{298}^{\circ}\right)$ show those from conductance (this paper) measurements.

With regard to the chemical model, the differences in the data analysis of calorimetric and conductance results are of minor importance, except the use of $R$ values from least squares fits of alkali metal salts. These $R$ values are systematically smaller than the estimated values used for conductance measurements; a re-evaluation of the conductance measurements (data in parantheses) exhibits the influence of $R$. The differences in absolute values are caused by the simple fact that the determination of $\Delta H_{298}^{\circ}$ and $\Delta S_{298}^{0}$ from conductance data requires the tangent at the curve $\Delta G_{\mathrm{T}}^{\mathrm{o}}$ vs. $T$ which is ill-defined at $25^{\circ} \mathrm{C}$. The temperature of $25^{\circ} \mathrm{C}$ is the highest temperature used in the conductance series (values of $K_{\mathrm{A}}$ and hence $\Delta G_{298}^{0}$ from conductance and calorimetric measurements are in good agreement) but the polynomial, Eq. (7a), doesn't reproduce the tangent at $25^{\circ} \mathrm{C}$ (end of the interval) with a sufficiently steep slope; tentative evaluations with polynomials of fourth degree yield good agreement also for the $\Delta H_{298}^{\circ}$ and $\Delta S_{298}^{\circ}$ values from both methods.

To sum up the results of this comparison, the patterns of $\Delta H_{298}^{0}$ and $\Delta S_{298}^{0}$ from conductance and calorimetric measurements are the same; arranged in increasing enthalpies or entropies yields the same sequence of salts in both series with the same significant step for $\Delta H_{298}^{\circ}$ and $\Delta S_{298}^{\circ}$ between alkali metal and tetraalkylammonium salts. Taking into account that the equality of the association constants $\left(K_{\mathrm{A}}\right.$ or $\left.\Delta G_{298}^{0}\right)$ and their temperature coefficients $\left(\Delta S_{298}^{\circ}\right)$ is a highly pretentious criterion for the reliability of the model, the agreement in Table VII is satisfactory.

\section{ACKNOWLEDGMENT}

We are grateful for the support of this investigation by the 'Fonds der Chemischen Industrie'. 


\section{REFERENCES}

1. J. Barthel, R. Neueder, F. Feuerlein, F. Strasser, and L. Iberl, J. Solution Chem. 12, 449 (1983).

2. J. Barthel, U. Ströder, L. Iberl, and H. Hammer, Ber. Bunsenges. Phys. Chem. 86, 636 (1982).

3. J. Barthel, Ber. Bunsenges. Phys. Chem. 83, 252 (1979).

4. J. Barthel, H.-J. Gores, G. Schmeer, and R. Wachter, in 'Non-aqueous Solutions in Chemistry and Modern Technology', Topics in Current Chemistry, Vol. III, F. Boschke, series ed., (Springer, Heidelberg, 1983), p. 33.

5. J. Barthel, J.-C. Justice, and R. Wachter, Z. Phys. Chem. N. F. 84, 100 (1973); revised by J. Barthel, R. Buchner, and H.-J. Wittmann, Z. Phys. Chem. N. F. 139, 23 (1984).

6. P. Walden, H. Ulich, and F. Laun, Z. Phys. Chem. 114, 275 (1925).

7. J. Barthel, R. Wachter, and H.-J. Gores, Modern Aspects of Electrochemistry, Vol. 13, B. E. Conway and J. O'M. Bockris, eds., (Plenum Press, New York, 1979), p. 1.

8. J. Barthel, H.-J. Gores, P. Carlier, F. Feuerlein, and M. Utz, Ber. Bunsenges. Phys. Chem. 87, 436 (1983).

9. J. Barthel, F. Feuerlein, R. Neueder, and R. Wachter, J. Solution Chem. 9, 209 (1980).

10. J. Barthel, R. Wachter, and H.-J. Gores, Faraday Discuss. Chem. Soc. 64, 285 (1978).

11. A. M. Shkodin, L. P. Sadovnichaya, and V. A. Podolyanko, Sov. Electrochem. (Engl. Transl.) 4, 644 (1968)

12. F. Hovorka and J. C. Simms, J. Am. Chem. Soc. 59, 92 (1937).

13. T. A. Gover and P. G. Sears, J. Phys. Chem. 60, 330 (1956).

14. G. Wikander and U. Isacsson, Z. Phys. Chem. N. F. 81, 57 (1972).

15. D. F. Evans and P. Gardam, J. Phys. Chem. 72, 3281 (1968).

16. R. De Lisi and M. Goffredi, Gazz. Chim. Ital. 103, 491 (1973).

17. R. Wachter and K. Riederer, Pure Appl. Chem. 53, 1301 (1981).

18. B. S. Krumgalz, JCS Faraday Trans. I 79, 571 (1983).

19. B. S. Krumgalz and J. Barthel, Z. Phys. Chem. N. F. 142, 167 (1984).

20. G. Marx and H. Nitsche, Z. Naturforsch. 32a, 187 (1977).

21. G. Marx and M. Mirza, Z. Naturforsch. 32a, 185 (1977).

22. D. S. Gill, J. Solution Chem. 8, 691 (1979).

23. R. L. Kay and D. F. Evans, J. Phys. Chem. 69 , 4216 (1965).

24. D. F. Evans, G. P. Cunningham, and R. L. Kay, J. Phys. Chem. 70, 2974 (1966).

25. D. F. Evans and T. L. Broadwater, J. Phys. Chem. 72, 1037 (1968).

26. D. F. Evans, J. Thomas, J. A. Nadas, and Sister M. A. Matesich, J. Phys. Chem. 75, 1714 (1971). 